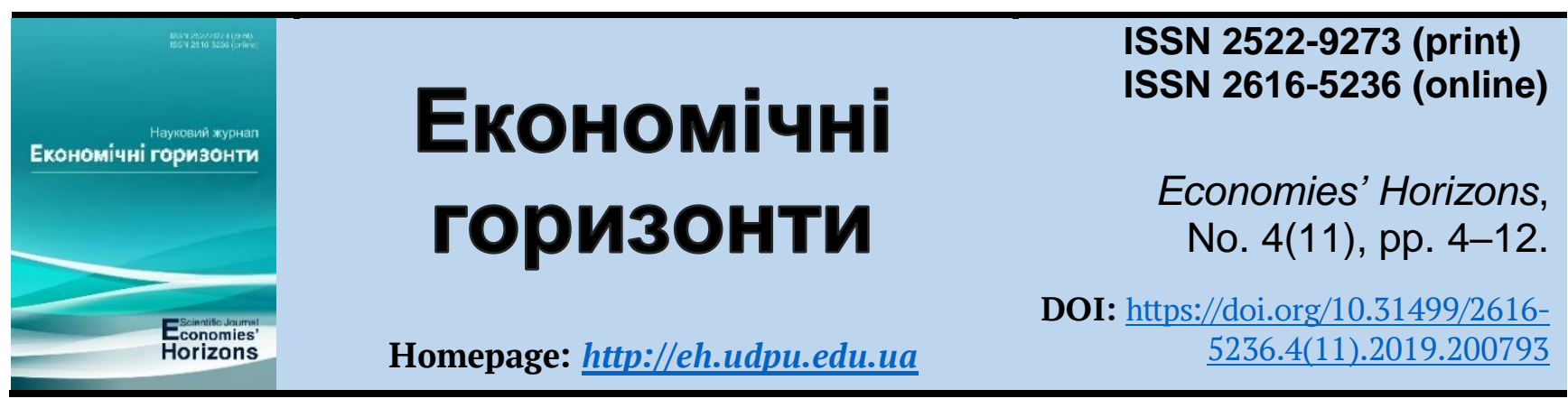

UDC 334.75:005.336.1

\title{
Synergistic effect in innovation clusters: essence and features of evaluation
}

\author{
Ihor M. Kuksa ${ }^{1}$, Doc. Ec. Sc., Professor \\ Olga P. Parkhomenko ${ }^{2}$, Cand. Ec. Sc., Associate Professor \\ Iryna A. Hnatenko ${ }^{3}$, Cand. Ec. Sc., Associate Professor \\ Viktoriia O. Rubezhanska ${ }^{4}$, Cand. Ec. Sc.
}

Received: 17 September 2019 Accepted: 21 October 2019
Kuksa, I. M., Parkhomenko, O. P., Hnatenko, I. A. and Rubezhanska, V. O. (2019), "Synergistic effect in innovation clusters: essence and features of evaluation", Economies' Horizons, no. 4(11), pp. 4-12, doi: https://doi.org/10.31499/2616$\underline{5236.4(11) .2019 .200793 . ~}$

Abstract. The purpose of the research. The purpose of the article is to determine the essence of the synergistic effect and to develop a common method for evaluating the phenomenon for further possible use in the analysis of the innovation cluster effectiveness. Methodology. In the course of the research, there were used general scientific theoretical methods: system analysis - to clarify the main categories of research; abstract-logical method - for realization of theoretical generalizations and conclusions about the essence of synergistic effect and peculiarities of its evaluation; graphical method - for visual presentation of theoretical and analytical material for the reflection of the main characteristics of synergetic effect in innovation clusters. Results. The article outlines the main characteristics of the innovation cluster and defines its role in formation of the competitive advantages for the national economy. The essence of the synergistic effect that arises in the process of interaction of innovation cluster participants is investigated. On the example of the functioning of large and small enterprises in the cluster the author illustrates schematically the positive synergistic effect of their interaction, and describes the main specific features of this effect. A general methodology for evaluating the synergistic effect in an innovation cluster is proposed based on grouping of the indicators system that will allow to evaluate the effectiveness of interaction processes between the innovation cluster participants. Practical meaning. The proposed general methodology for evaluating the synergistic effect in an innovation cluster can be used by its participants in the process of determining the effectiveness of their integration and developing appropriate measures to regulate the activity of the cluster. Prospects for further research. Carrying-out of the theoretical substantiation of the choice and calculation of certain indicators for the evaluation of the synergistic effect in the innovation cluster. Development of alternative forecasts for the innovation cluster development based on the results of the evaluation.

\footnotetext{
${ }^{1}$ Luhansk National Agrarian University; Head of the Department of Finance, Taxation and Information Technology; ORCID ID: http://orcid.org/0000-0001-8486-2473; e-mail: igor.kuksa.23@gmail.com.

${ }^{2}$ Kyiv National Economic University named after Vadim Hetman; Associate Professor of the Department of Audit; ORCID ID: http://orcid.org/0000-0003-3159-9653; e-mail: olpa@meta.ua.

${ }^{3}$ Kyiv National University of Technologies and Design; Doctoral Student; ORCID ID: https://orcid.org/00000002-0254-2466; e-mail:q17208@ukr.net.

${ }^{4}$ Luhansk Taras Shevchenko National University; Senior Lecturer of the Department of Finance, Accounting and Banking; ORCID ID: https://orcid.org/0000-0001-8047-4000; e-mail: rubezhiik@gmail.com.
} 
Kuksa I. M., Parkhomenko O. P., Hnatenko I. A., Rubezhanska V. O. Synergistic effect in innovation clusters: essence and features of evaluation

Keywords: innovation process, integration, synergy, cluster, specific features of synergistic effect, estimation methodology architectonics of synergistic effect.

JEL Classification: M21, O10, R38.

Number of references: 11; number of tables: 0; number of figures: 3; number of formulas: $\mathbf{0 .}$

\title{
Синергетичний ефект в інноваційних кластерах: сутність та особливості оцінювання
}

\author{
Ігор Миколайович Кукса ${ }^{1}$, д. е. н., професор \\ Ольга Петрівна Пархоменко ${ }^{2}$, к. е. н., доцент \\ Ірина Анатоліївна Гнатенко ${ }^{3}$, к. е. н., доцент \\ Вікторія Олегівна Рубежанська ${ }^{4}$, к. е. н.
}

Стаття надійшла: 17.09.2019 Стаття прийнята: 21.10.2019
Kuksa I. M., Parkhomenko O.P., Hnatenko I. A., Rubezhanska V. O. Synergistic effect in innovation clusters: essence and features of evaluation. Економічні горизонти. 2019. № 4(11). C. 4-12. DOI: 10.31499/2616-5236.4(11).2019.200793.

Анотація. Мета дослідження. Мета статті - визначення сутності синергетичного ефекту та розробка загальної методики оцінювання зазначеного явища для подальшого можливого використання в процесі аналізу ефективності функціонування інноваційного кластера. Методологія. У процесі виконання дослідження використано загальнонаукові теоретичні методи: системний аналіз - для з'ясування основних категорій дослідження; абстрактно-логічний метод - для здійснення теоретичних узагальнень та висновків про сутність синергетичного ефекту та особливості його оцінювання, графічний метод - для наочного представлення теоретичного й аналітичного матеріалу щодо відображення основних характеристик синергетичного ефекту в інноваційних кластерах. Результати. У статті виділено основні характеристики інноваційного кластеру та визначено його роль у формуванні конкурентних переваг для національної економіки. Досліджено сутність синергетичного ефекту, який виникає в процесі взаємодії учасників інноваційного кластеру. Авторами на прикладі функціонування великого та малого підприємства у складі кластера схематично відображено позитивний синергетичний ефект від їхньої взаємодії, охарактеризовано основні специфічні ознаки зазначеного ефекту. Запропоновано загальну методику проведення оцінювання синергетичного ефекту в інноваційному кластері на основі групування системи показників, які дозволять оцінити ефективність процесів взаємодії між учасниками інноваційного кластера. Практичне значення. Запропонована загальна методика оцінювання синергетичного ефекту в інноваційному кластері може бути використана його учасниками в процесі визначення ефективності функціонування їх об'єднання та розробки відповідних заходів з регулювання діяльністю кластера. Перспективи подальших досліджень. Здійснення теоретичного обгрунтування вибору та розрахунку певних показників для проведення оцінювання

\footnotetext{
1 Луганський національний аграрний університет; завідувач кафедри фінансів, оподаткування та інформаційних технологій; ідентифікатор ORCID: http://orcid.org/0000-0001-8486-2473; e-mail: igor.kuksa.23@gmail.com.

${ }^{2}$ Київький національний економічний університет імені Вадима Гетьмана; доцент кафедри аудиту; ідентифікатор ORCID: http://orcid.org/0000-0003-3159-9653; e-mail: olpa@meta.ua.

${ }^{3}$ Київський національний університет технологій та дизайну; докторант; ідентифікатор ORCID: https://orcid.org/0000-0002-0254-2466; e-mail: q17208@ukr.net.

${ }^{4}$ Луганський національний університет імені Тараса Шевченка; старший викладач кафедри фінансів, обліку та банківської справи; ідентифікатор ORCID: https://orcid.org/0000-0001-8047-4000; e-mail: rubezhiik@gmail.com.
} 
синергетичного ефекту в інноваційному кластері. Розробка альтернативних прогнозів розвитку інноваційного кластера на основі результатів зазначеного оцінювання.

Ключові слова: моделювання, взаємодія, влада, громада, публічне управління, електронні ЗМІ, експерт, аналітик.

Кількість джерел: 11; кількість таблиць: 0; кількість рисунків: 3; кількість формул: 0.

\section{Introduction.}

The ever-increasing international competition stipulates the relevance of the theoretical analysis and the search for new forms of accelerated economic development and increase the competitiveness of the country and individual territories. In this regard, production innovations, that is, improvements in the field of engineering, technology, organization of finished products production, should be an integral part of the production and economic activities of any economic systems that care about their future. In the context of globalization of world economic development, there is a need for further structural transformations in national economies and formation of more advanced innovative production systems on this basis.

World experience demonstrates the high efficiency of cluster integration, which is an element of structural economic transformation based on the methods of economic growth management. This is due to the fact that the members of the innovation cluster retain their independence and acquire strong mutual organizational, financial and other relationships that make corporate structural entities the most stable and reliable. In the cluster, competitive advantage is created through the sharing of factors of production, technology, information, the formation of specialized infrastructure and coordination of actions with other related companies based on common interests. In this regard, the main feature of the cluster is the emergence of a synergistic effect in the interaction of its members. The synergistic effect implies an increase in the effectiveness of the joint activity of the cluster participants through the concentration of interests and resource potential of several organizations in one project, which, in turn, determines the relevance of the study of this phenomenon.

\section{Literature review.}

The research of innovative clusters, peculiarities of their functioning, as well as the synergistic effect of the interaction of its clusters is devoted to many scientific works of domestic and foreign scientists. Thus, S. Rosenfeld (2005) examines the process of clusters evolution from networks, describes the main strategies for cluster development and their application in practice (Rosenfeld, 2005). A. Rauch, R. Doorn, and W. Hulsink (2014) consider cases of increase in the performance of the enterprises caused by belonging to the business clusters (Rauch, Doorn, and Hulsink, 2014). The research of O. Odintsov (2012) deals with the main advantages of creating and operating agro-industrial clusters that contribute to the sustainable development of the agroindustrial complex at the regional and state levels (Odintsov, 2012).

M. Porter (2005) in the study of the essence of the synergistic effect in the cluster analyzed three types of interconnections between participants of the innovation cluster (tangible, intangible and competing interconnections). In addition, the concept of value chains proposed by the author is used to identify common activities within the cluster and their relationships that can be used to create competitive advantage and which represent themselves sources of synergy (Porter, 2005).

In the scientific work of L. Lisovska and N. Hryniv (2016) the sources of synergism generation are identified, the sources of synergy in innovations are defined and classified, the types of synergetic effects are substantiated and their manifestation by stages of the innovation process is investigated (Lisovska and Gruniv, 2016). I. Holik (2015) there were studied the peculiarities of the synergistic effect manifestation of cluster associations in a 
Kuksa I. M., Parkhomenko O. P., Hnatenko I. A., Rubezhanska V. O. Synergistic effect in innovation clusters: essence and features of evaluation

market economy and worked out a scheme of sources for obtaining the synergistic effect of innovative cluster formations (Holik, 2015). In the article by A. Polianska and S. Afonkin (2013) the calculation of the synergy coefficient is made, which allows to take into account the potential opportunities that can be used for more efficient management of the enterprise within the cluster (Polianska and Afonkin, 2013).

In paying tribute to the aforementioned scientific works, it should be noted that there is a lack of research in the field of creating specific practical synergistic management tools in innovation clusters.

\section{Methods.}

In the course of the research, there were used general scientific theoretical methods: system analysis - to clarify the main categories of research; abstract-logical method - for realization of theoretical generalizations and conclusions about the essence of synergistic effect and peculiarities of its evaluation, graphical method - for visual presentation of theoretical and analytical material for the reflection of the main characteristics of synergetic effect in innovation clusters.

\section{Research objectives.}

The purpose of the article is to determine the essence of the synergistic effect and to develop a general methodology for evaluating the phenomenon for further possible use in the analysis of the innovation cluster effectiveness.

\section{Results and discussions.}

In contemporary conditions, the competitive advantages of the national economy are decisively determined by its ability to accelerate the creation and implementation of the latest technics, technology in all spheres of business. In our opinion, the most effective form of integration of enterprises and organizations performing various functions in a common technological process, resulting in a knowledge-intensive product, is an innovative cluster. In general, the innovation cluster is an organizational and economic form of implementation of the innovation system in the economy of any level and it serves as a catalyst for innovation in each specific sector of economy and region. The main characteristics of the innovation cluster, according to which it can be distinguished among other types of cluster formations, are shown in Fig. 1.

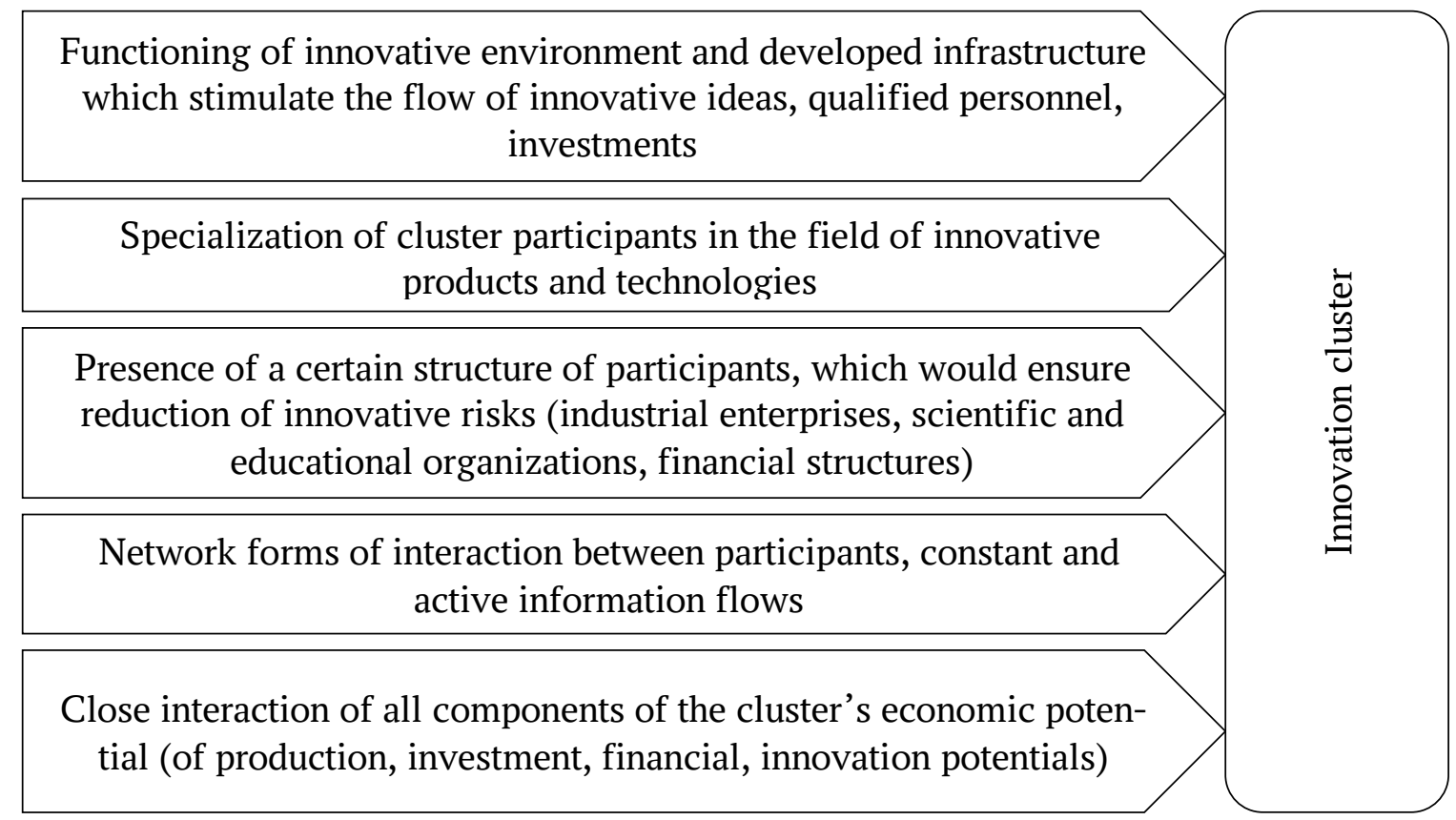

Fig. 1. The main characteristics of the innovation cluster

Source: created by the authors. 
The role of innovation clusters they play in the economic development of any country is reflected in the functions they carry out. We agree with M. Porter's opinion, which identifies several functions performed by clusters, including the innovative ones: clusters are critical engines in the economic structure of the national and regional economy, since the prosperity of the region (country) depends on significant positions in a certain number of competitive clusters; clusters can define fundamental tasks in national or regional business contexts because they are highly correlated with the nature of competition and the microeconomic factors that affect competitive advantage; clusters provide a new way of thinking in the field of economics and efforts to develop its organization, as they help to redefine the roles of the private sector, government, educational and research institutions in economic development, and to identify the overall capabilities of enterprises of all ownership forms (Porter, 2005).

In its essence, the innovation cluster is an innovative and synergistic complex formed on the basis of an industrial enterprise autonomously and in cooperation with industrial and research organizations, integrating innovative, information and investment flows in the structure on the basis of development and implementation of innovation and investment projects in accordance with the internal strategy of the organization, the level of the industry development and the state strategy of innovation and economic development. That is, one of the main properties of an innovation cluster is the presence of synergistic effect from the interaction of its participants.

It should be noted that, according to the theory of economic synergy, the synergistic effect is the result of the coherent action of the constituent components of the economic system, which causes qualitative changes in its state and keeps the development of the system stable, despite exogenous influences and endogenous fluctuations. Fluctuations are exacerbated by the imbalance that arises in the system, which leads to the loosening of the previous structure and the emergence of a new one. As a result, a new structure emerges and a new order stems from the chaos appeared. Thus, from the point of view of the synergistic approach, the evolution of complex economic systems, which can be attributed to the innovation cluster, is realized through stochastic (probable) fluctuations and bifurcations (Gnatenko and Rubezhanska, 2017, p. 111).

We share opinion of $\mathrm{O}$. Budarov that the formation of synergistic interaction involves the transition from one equilibrium state to another equilibrium state at a higher organizational level. In the previous equilibrium, business units, while operating individually, achieve maximum efficiency and minimize costs at the same level. After the transition to a new equilibrium, which implies the integrity of business units, an increase in efficiency and cost minimization take place (Budarov, 2010).

It should be emphasized that in production systems focused on the creation and implementation of innovative products, there is a need to reconcile the long-term goals and interests of different participants in the integration process, since cooperation is carried out at all stages of the reproduction and innovation cycles. It is the long-term goals that are formed on the basis of shared interests and in the context of collective development that underpin the realization of long-term synergy (Reryh, 2014, p. 82).

The emergence of a synergistic effect in a cluster depends on many factors, including: number of cluster participants, availability of resources, proximity to consumers, competitors, as well as companies that supply components, materials and services to achieve the effect of agglomeration. Equally important are the flows of information, technological progress, innovation, the professional level of labor, the flows of capital and labor inside and outside the cluster. The effect of synergy in the cluster is facilitated by the independence of its members from one another. Competition among cluster members causes them to increase their own competitive advantages, which leads to the elimination of inefficient 
forms of functioning. Each participant develops its strengths, transferring the underdeveloped functions to other structures, which provides for the implementation of the principle of cluster members complementarity, as well as it leads to an increase of synergistic effect.

Thus, a synergistic effect implies an increase in the effectiveness of a collaborative activity by focusing on a long-term base on one project of interests and the resource potential of several organizations strategically allied to one another. (Gnatenko and Rubezhanska, 2018). In other words, the sum of the effects obtained from each participant in the innovation cluster separately is less than the total sum of the results obtained from the joint actions of the mentioned participants in the cluster. Conversely, the sum of the results obtained from joint actions in the cluster is greater than the sum of the results obtained from each participant of the innovation cluster individually.

It is to be noted that the main problems faced by enterprises (irrespective of their size and ownership) in the process of their autonomous (independent) innovation activity disappear when merging economic entities into the innovation cluster due to the emergence of a synergistic effect, which is characterized by certain specific features (Fig. 2).

It is proposed to consider the specific features of the synergistic effect in the innovation cluster in more detail.

In the cluster which exist for a long period of time, the process of knowledge flow occurs through suppliers, consumers, consulting firms, former employees, as well as it is absorbed by employees during training and transmitted through personal communication, through social networks, etc. The level of knowledge acquired in this process may be an indicator of whether an enterprise is capable of achieving a knowledge-based advantage, that is, of whether knowledge leads to competitive advantage (Holik, 2015).

The synergistic effect in the innovation cluster stipulates changes in the size of cash accretion and outflows. The increase in cash flow is associated with an increase in aggregate demand for products in the context of a cluster, with a complication of purchasing advantages that require the improvement of goods and services. Reduced cash outflows are associated with increased productivity of its participants, costs cutting for production and sales of products, reduced specificity and increased availability of various resources (primarily human resources), increased accessibility and reduced cost of specialized information, reduced business risk and reduced costs of business security and, overall, by increasing of internal competition.

The effect of sharing a cluster infrastructure is to reduce the individual costs of forming a cluster for each individual participant, and to reduce the cost of its maintenance and use. At the same time, we are talking about objects of transport, energy, engineering, housing and social infrastructure of cluster development. Sharing of a cluster of logistic infrastructure, energy systems, information networks, marketing developments by enterprises allows to obtain services of higher quality at a lower cost.

The effect of reducing transaction costs in the innovation cluster is due to knowledge flow. Cluster enterprises have access to specific resources, which the cluster possesses in total and which are transferred from one participant to another, forming a common knowledge base of the cluster and reducing transaction costs (Odintsov, 2015).

The effect of innovation emergence growth is determined by the high speed of exchange of information on needs and technologies between the cluster participants, enterprises of related industries, research centers, design organizations and small businesses, which usually act in the cluster as generators of ideas and primary testers of new technologies.

The effect of attracting additional investment is determined by the mere fact of the cluster's existence as a coherent economic system. The activity of the cluster attracts the 
attention of its members from financial structures, allows to receive assistance in building credit reputation, in the distribution of enterprises advertising within the brand of the

\begin{tabular}{|l|}
\hline $\begin{array}{l}\text { Lack of own financial } \\
\text { resources to develop in- } \\
\text { novative product / busi- } \\
\text { ness expansion }\end{array}$ \\
\hline \hline $\begin{array}{l}\text { Lack of consumer } \\
\text { awareness of the new } \\
\text { product brand and its } \\
\text { manufacturer }\end{array}$ \\
\hline \hline $\begin{array}{l}\text { Absence of own pro- } \\
\text { duction, marketing re- } \\
\text { sources for develop- } \\
\text { ment of innovative } \\
\text { product / business ex- } \\
\text { pansion }\end{array}$ \\
\hline
\end{tabular}

Impossibility of batch production / commercialization sources cluster, as well as contributes to the additional resources proceeds to the region which the innovation cluster operates in. due to lack of financial re-

Insufficient human or entrepreneurial resources, lack of production specialization to implement an innovative idea

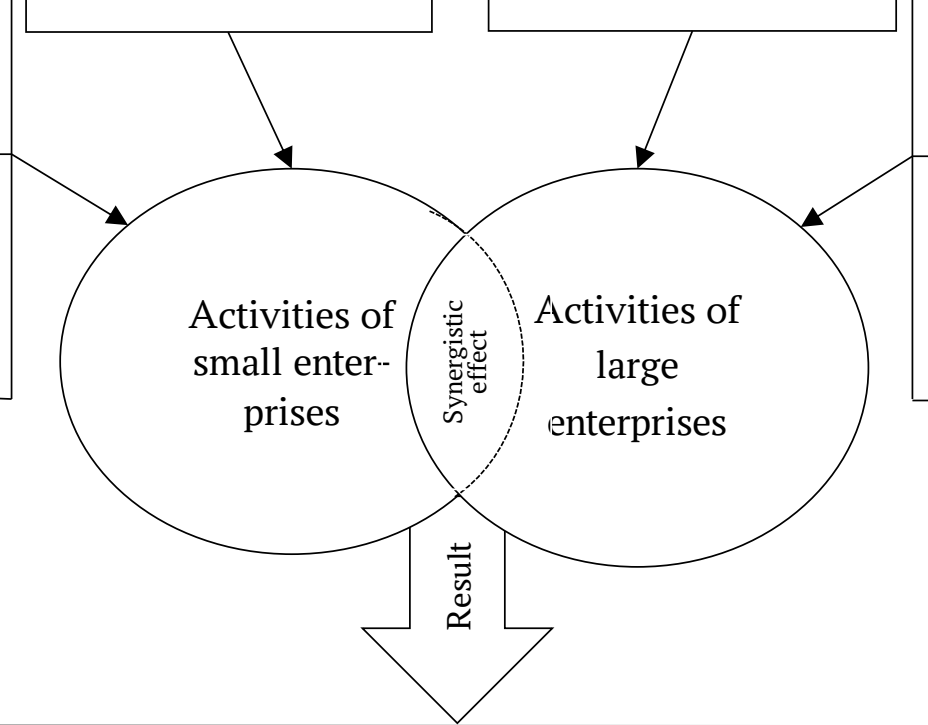

Significant costs of creating the marketing networks required to market small batch markets

Difficulty with managing a large business effectively (long decisionmaking)

Congestion or lack of production capacity, insufficient order volume for a large enterprise

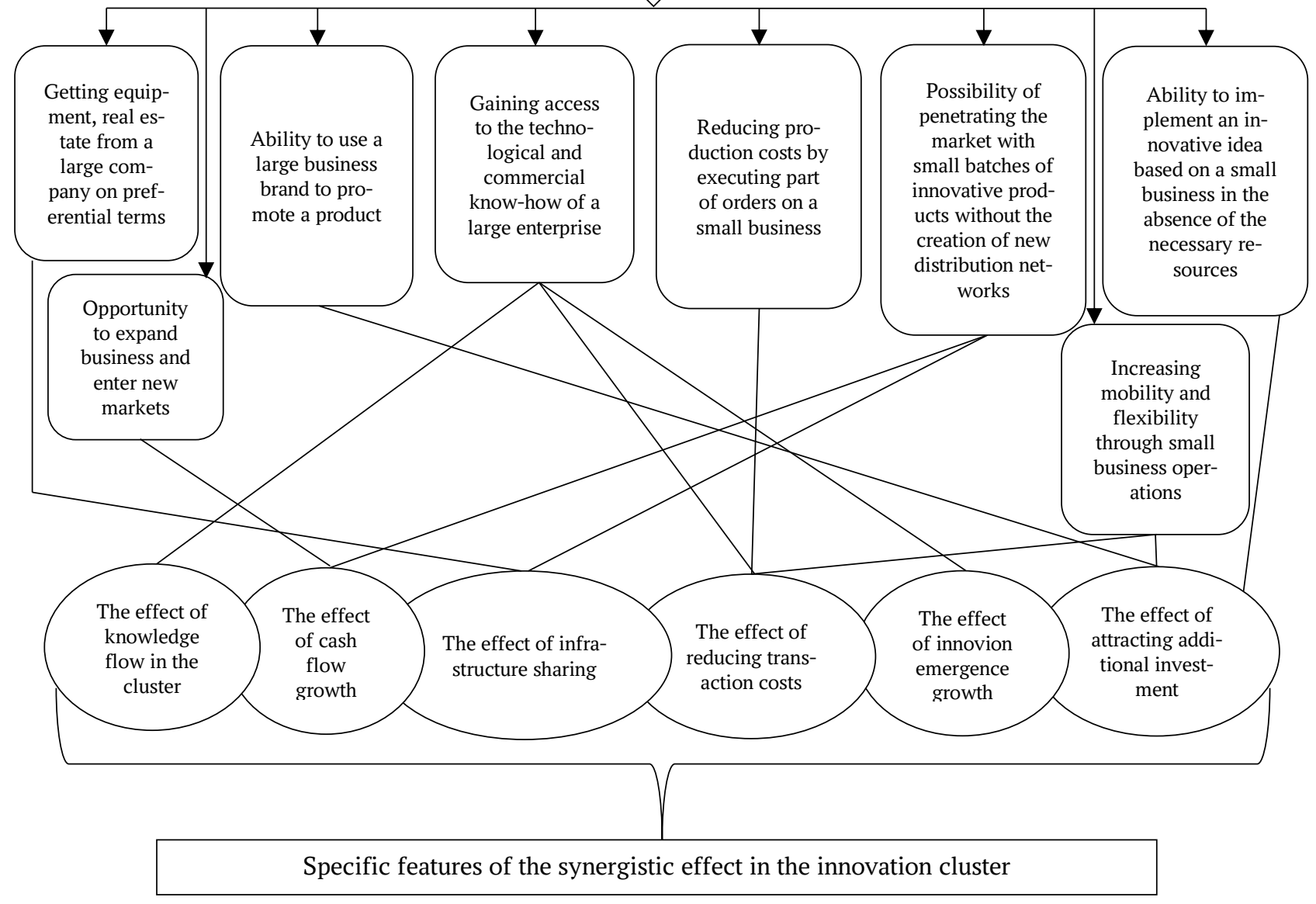

Fig. 2. Positive synergetic effect of joint activity of large and small enterprises in the innovation cluster

Source: created by the authors. 
It should be noted that in practice, defining a synergistic effect in an innovation cluster is not always possible because of the difficulty in obtaining the source information. In this regard, the urgent task is to develop a methodology for evaluating the synergistic effect of integration processes, which will take into account various forms of synergy. Fig. 3 demonstrates in general one of the possible groupings of the indicators system that will allow to evaluate the effectiveness of the interaction processes between the participants of the innovation cluster (Fig. 3). The proposed grouping of indicators provides for their formalization according to the components of the aggregate potential of the cluster.

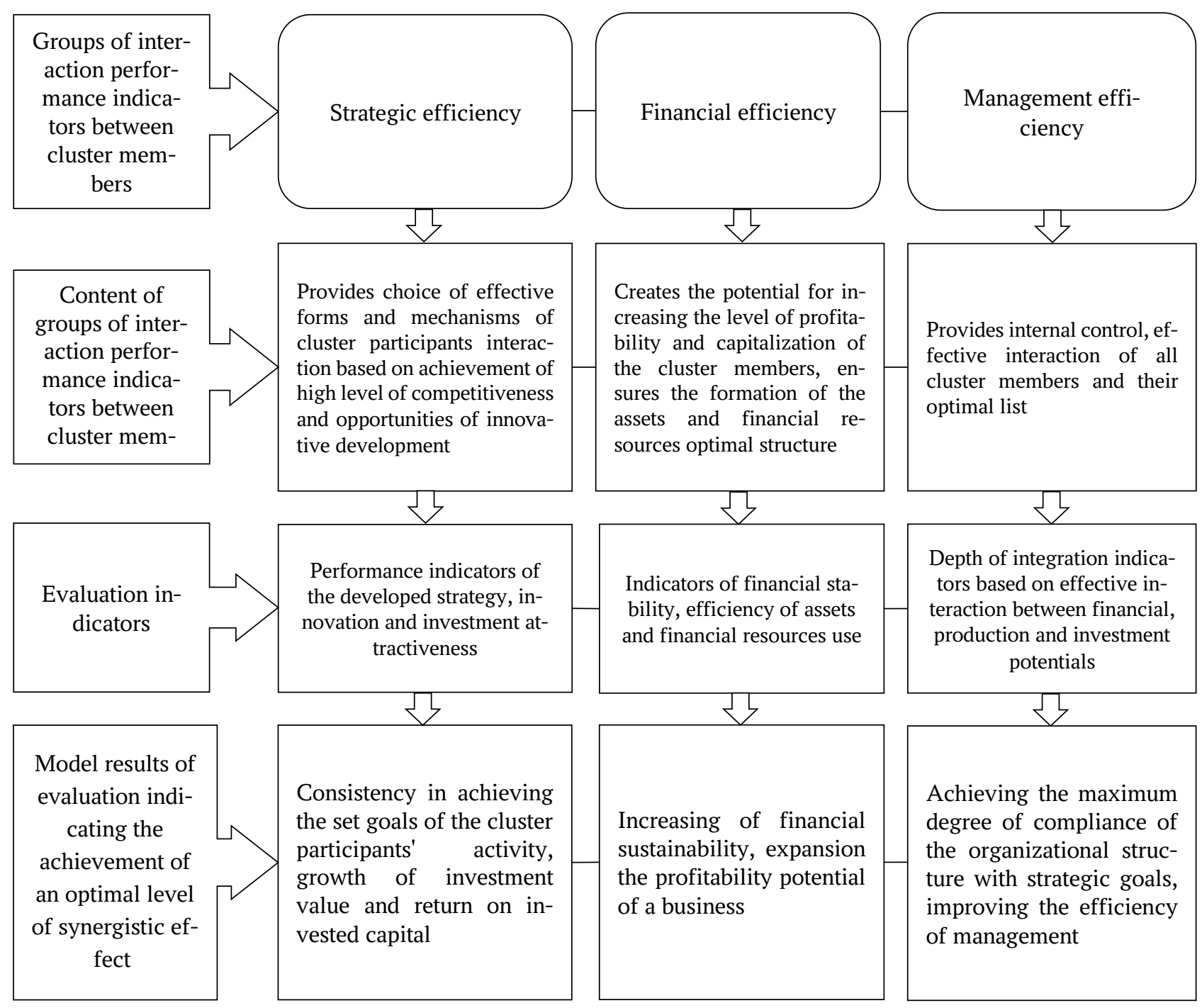

Fig. 3. Architectonics of a technique for evaluation the synergistic effect within an innovation cluster

Source: developed by the authors.

In our opinion, the grouping of indicators shown in Fig. 3 can be used as a methodological basis in the formation of a methodology for evaluating the synergistic effect, which is determined in terms of components of the aggregate potential of the innovation cluster, namely of the production, investment, financial, in- vestment one. An important step in this methodology is the calculation of the integral synergistic effect index, taking into account the interaction of all components of the aggregate potential of the cluster and the subsequent determination of the economic effect obtained as a result of the enterprises resources integration that are part of the innovation cluster. 


\section{Conclusions.}

As a result of the research, it can be noted that the problem of national economy competitiveness can be solved by forming innovative clusters as a modern form of integration interaction of business entities, which involves the creation of long-term competitive advantages, increasing the efficiency of processes and the efficiency of using available resources through effective management of interaction of all economic potential elements of the cluster members, which in turn will allow to reach the greatest possible synergistic effect and to make the most reasonable and appropriate decisions in the conditions of globalization of the world economic development. It is worth pointing out that an important component of ensuring the effectiveness of the innovation cluster is timely evaluation of the synergistic effect of its participants' interaction and the development of appropriate measures to regulate the activities of enterprises that are part of the cluster, depending on the results of such evaluation.

\section{References}

Budarov, A. Y. (2010), "Sinergiya i ekonomicheskiy rezonans pri vzaimodeystvii biznes-edinits", Vestnik VGU. Serija: Jekonomika $i$ Upravlenie, no. 1, pp.62-65, available at: http://www.vestnik.vsu.ru/pdf/econ/2010/01/2010-01-10.pdf (Accessed 11 September 2019).

Gnatenko, I. and Rubezhanska, V. (2018), "Architectonics of the concept of the national labour market regulation”, Management, vol. 1, no. 27, pp. 79-90, doi: https://doi.org/10.30857/2415-3206.2018.1.7.

Gnatenko, I. A. and Rubezhanska, V. O. (2017), "The logic of introducing innovation activities into the regional labor market in the context of its cyclical development", Business Inform, no. 8, pp. 110-115.

Holik, I. L. (2015), "Synergetic effect of clusters formations", Efektyvna ekonomika, [Online], no. 5, available at: http://www.economy.nayka.com.ua/?op=1\&z=4053 (Accessed 11 September 2019).

Lisovska, L. S. and Hryniv, N. T. (2016), "Providing synergy of the innovation process in the enterprise", Visnyk Natsionalnoho Universytetu "Lvivska Politekhnika". Lohistyka, no. 846, pp. 103-109.

Odintsov, O. M. (2012), "Factors for combining the interests of enterprises in the integrated cluster systems of agriculture", Efektyvna ekonomika, [Online], no. 2, available at: http://www.economy.nayka.com.ua/?op=1\&z=1406 (Accessed 11 September 2019).

Polianska, A. and Afonkin, S. (2013), "Synergy effect determination in the process of management decision making”, Economy, no. 5(125), pp. 87-89.

Porter, M. (2005), Konkurentnoe preimushhestvo: kak dostich' vysokogo rezul'tata i obespechit' ego ustojchivost' [Competitive advantage: how to achieve high results and ensure its sustainability], Al'pina Biznes Buks, Moscow, Russia, 341 p.

Rauch, A., Doorn, R. and Hulsink, W. (2014), “A qualitative approach to evidence-based entrepreneurship: theoretical considerations and an example involving business clusters", Entrepreneurship Theory and Practice, vol. 38, no. 2, pp. 333-368, doi: https://doi.org/10.1111/etap.12093.

Reryh, L. M. (2014), "Formation of long-term synergy within the processes of integration and clustering on the way to innovative economy”, Problemy Suchasnoyi Nauky ta Osvity, vol. 9(27), pp. 81-84.

Rosenfeld, S. (2005), "Industry clusters: business choice, policy outcome, or branding strategy?", Journal of New Business Ideas and Trends, vol. 3, issue 2, pp. 4-13, available at: http://jnbit.org/upload/Rosenfeld-3-22005.pdf (Accessed 11 September 2019).

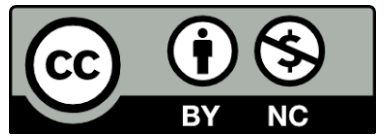

Цей твір ліцензовано на умовах Ліцензії Creative Commons «/з Зазначенням Авторства - Некомериійна 4.0 Міжнародна» (CC BY-NC 4.0). This is an open access journal and all published articles are licensed under a Creative Commons "Attribution-NonCommercial 4.0 International" (CC BY-NC 4.0). 